\title{
THE EFFECT OF INSTITUTIONAL OWNERSHIP AND \\ EXECUTIVE COMPENSATIONON COMPANY \\ PERFORMANCE (STUDY ON FOOD AND BEVERAGE \\ INDUSTRY LISTED IN INDONESIASTOCK EXCHANGE \\ FROM 2014-2018)
}

\author{
Yunita Riaswati ${ }^{1}$ \\ ${ }^{1}$ Faculty of Economics, Universitas Negeri Jakarta \\ Jakarta, Indonesia \\ yunitariaswati97@gmail.com \\ Suherman ${ }^{2}$ \\ ${ }^{2}$ Faculty of Economics, Universitas Negeri Jakarta \\ Jakarta, Indonesia \\ suherman@unj.ac.id \\ Umi Mardiyati ${ }^{3}$ \\ ${ }^{3}$ Faculty of Economics, Universitas Negeri Jakarta \\ Jakarta, Indonesia \\ Umi.mardiyati@gmail.com
}

\begin{abstract}
The purpose of this study is to determine the effect of institutional ownership and executive compensation on company performance in the food and beverage industry listed on the Indonesia Stock Exchange from 2014-2018. The variables used in this study are institutional ownership and executive compensation as independent variables, company performance (proxied by Tobin's Q, ROA, and ROE) as the dependent variable, as well as company size, leverage (proxied by DAR), and company age as the control variable. The sampling method used was the purposive sampling method, with the balanced panel data as a data analysis method. The results of this study indicate that institutional ownership has a significant positive effect on company performance (on Tobin's Q proxy) and insignificant (on ROA and ROE), while executive compensation does not have a significant effect on company performance.
\end{abstract}


Keywords: Company Performance, Institutional Ownership, Executive Compensation, Food and Beverages Companies

\section{INTRODUCTION}

Currently, the discussion about corporate governance is one of the topics that are quite widely researched. This is because the implementation of good corporate governance by a company can help ensure that the company continues to grow and develop in the long term. The implementation of good corporate governance can be the answer for companies to face economic challenges.

The implementation of GCG in Indonesia is still not too massive but shows a pretty positive trend. Currently, good corporate governance has become an obligation for public companies listed on the Indonesia Stock Exchange (IDX). Along with developing the concept of good corporate governance, The Indonesian Institute for Corporate Governance (IICG) was formed as an independent institution that carries out dissemination and development of good corporate governance in Indonesia. They conduct research and ratings on implementing good corporate governance in companies, with a system known as the Corporate Governance Perception Index (CGPI) (Mirawati \& Wulansari, 2018).

Other than that, in the 2019 ASEAN Corporate Governance Scorecard (ACGS) assessment of listed companies with the largest market capitalization in each ASEAN country (Philippines, Indonesia, Malaysia, Singapore, Thailand, Vietnam), there were ten issuers from Indonesia out of 100 companies in Southeast Asia that entered in the ASEAN Asset Class category. The number of issuers has increased compared to 2015 and 2017 (with two issuers and eight issuers respectively). This increase shows the progress of GCG in Indonesia towards a better direction.

However, of all these issuers, no issuer comes from the Food and Beverages sector. This is very unfortunate because this sector can be considered as an industry that never dies. After all, it is the primary human need and cannot be replaced. Therefore, the implementation of GCG for companies in this sector must be improved to ensure that the 
company continues to grow and develop in the long term and improve the company's performance.

Company performance is one of the benchmarks in seeing the good or bad of a company. If the company is listed on the stock exchange, maximizing the company's performance is one of the main goals because high company performance can increase company value. The company's value reflects the company's performance in carrying out its operational activities since the company was founded now. Increasing the company's value is a goal that suits the owner of the company because with the increase in the value of the company, the welfare of the owner will increase. This will affect the company's attractiveness for investors to buy company shares because high company value will maximize share prices, thereby increasing welfare for shareholders or investors, and in the end, it will provide benefits for the company (Nugraha, 2018).

A qualified GCG application can unite the interests of company management and the interests of shareholders in managing the company. Talking about shareholders, one form of corporate share ownership structure is institutional ownership. Institutional ownership is the ownership of company shares owned by institutions or institutions such as insurance companies, banks, investment companies, and other institutional ownership. Institutional ownership will encourage an increase in more optimal supervision of management performance (Fadillah, 2017).

Several studies have looked at the effect of institutional ownership on company performance. Lin \& Fu (2017) and Maharani \& Utami (2019) state that institutional ownership has a significant positive effect on company performance because the greater the value of institutional ownership, the stronger the control over the company so that company owners can control management behaviour to act under company goals. Which in turn will improve company performance. However, these results contradict research conducted by Fadillah (2017) which states that institutional ownership has a significant negative effect on company performance and Amba (2014), which states that institutional ownership has no significant effect.

Another factor that has an essential role in implementing GCG in a company is executive compensation. Agency conflict occurs when agents (board of commissioners and directors) use the information they have to make decisions that benefit themselves, 
resulting in losses on the part of the principal (the party contracting the agent, the shareholders). Berger et al. (2013) stated that compensation is one of the tools that can be used to control corporate governance boards in reducing agency conflict. Therefore, in addition to compensation, it can be used to align the interests of shareholders with company executives, and it can also be used to motivate company executives to work better, which will impact improving company performance.

Several studies have looked at the effect of executive compensation on company performance. Kagango (2016) and Abdalkrim (2019) state that executive compensation has a significant positive effect on company performance. It is explained that, by providing reasonable compensation, the executive will be triggered to try to improve the company's performance. This result contradicts the study of Matolcsy et al. (2012), which states that executive compensation has a significant negative effect on company performance and Bianchi \& Chen's research (2015), which states that executive compensation has no significant effect on company performance.

Based on the background and differences in the research results described above, the researcher is interested in conducting a study titled "The Effect of Institutional Ownership and Executive Compensation on Company Performance (Study on Food and Be verage Industry Listed in Indonesian Stock Exchange From 2014-2018)". In addition to the many different previous research results that causeresearch gaps, there are still not many studies that discuss the influence of GCG on company performance that specifically discusses companies in the food and beverage sector.

With that being said, there are several objectives that the research is striving for:

1. To determine the effect of institutional ownership on the performance of food and beverage companies listed on the Indonesia Stock Exchange for the period 2014-2018

2. To determine the effect of executive compensation on the performance of food and beverage companies listed on the Indonesia Stock Exchange for the period 2014-2018. 


\section{LITERATURE REVIEW}

\section{Company Performance}

The company as a form of organization has specific objectives to be achieved to fulfil the interests of the company's stakeholders. According to Fadillah (2017), company performance is a measuring tool that can be used to assess a company's success in achieving company goals. Then according to Rahmawati \& Handayani (2017), company performance is a work achievement achieved by the company in a certain period which is the result of the work process that occurs in that period. Based on these explanations, it can be concluded that the company's performance is a description of the condition of a company as seen by specific measurement methods so that it can reflect the work performance of the company and the good and bad con ditions of the company can be seen in a certain period.

\section{Institutional Ownership}

Institutional ownership is the ownership of company shares owned by other institutions or institutions such as insurance companies, banks, investment companies, and other companies. The existence of share ownership by institutional investors will encourage more optimal supervision of management performance (Fadillah, 2017). This was explained by Fazlzadeh et al. (2011), where the reason why institutional ownership is more capable of supervising is that they are believed to have the resources and ability to supervise management decision making adequately. Wulandari (2013) adds, the higher the institutional ownership, the stronger the external control on the company will be and can reduce agency costs experienced by the company. This is because, with solid external controls, management will be more careful in making decisions.

\section{Executive Compensation}

According to Anggraini et al. (2014), compensation can be considered remuneration related to the economic justice system for parties involved in organizing economic activities. Every employee, board, and management always pay attention to everything related to compensation. From the perspective of executive compensation, compensation is the reward they get as agents, where they have the responsibility to optimize the profits of the principals. In addition, they can also receive bonuses if they succeed in improving the company's performance. Kagango (2016) explains that the compensation received by 
executives is determined based on company policy itself so that each company has different types of compensation. The most basic form of compensation is the basic salary received. In some companies, to align the interests of executives with shareholders, compensation can be given by share ownership, so that the compensation received depends on how well the company is performing.

\section{Company Size}

Company size describes how big or how small a company is as measured by various indicators, including the company's total assets, log size, and stock market value. In addition, company size can also be measured through total assets, total sales, average sales of assets, and average total assets of the company (Novari \& Lestari, 2016). The larger the company's size, the greater the funds managed, so it can be ascertained that the company's management will become increasingly complex.

\section{Leverage}

Leverage is the company's ability to fulfil its financial obligations and can also be used to see how much the company is financed using debt (Novari \& Lestari, 2016). Leverage is also used to measure how far borrowed funds finance the company. Leverage is divided into two types where operational leverage is the leverage that arises when the company uses assets that have fixed operating costs. At the same time, financial leverage is a source of funds or external sources of financing that the company uses to allocate assets or invest (Sari \& Priyadi, 2016).

\section{Company Age}

The company's age is a description of how long a company has been in existence so that the company is still able to carry out its operational activities. By looking at the company's age, investors can conclude whether the company can continue to survive and be able to compete for business opportunities (Halim \& Christiawan, 2019). With a good understanding of the industry, companies that have been established for a longer time tend to act more carefully in managing the company, resulting in more efficient management (Nurwati et al., 2014). 


\section{Research Hypotheses}

\section{The Effect of Institutional Ownership on Company Performance}

Maharani \& Utami (2019) state that institutional ownership has a significant positive effect on company performance. This is explained, the higher the institutional ownership that is owned, the stronger the control that the institution has over the company so that the institution that acts as the owner of the company can control management behaviour so that it acts under company goals which will ultimately improve company performance. In addition, Lin \& Fu (2017) research explains that institutional ownership can actively oversee company business activities, minimize information gaps and agency problems, and help company performance in two ways. First, institutional investors can use their managerial abilities, professional knowledge, and voting rights to influence managers in improving corporate efficiency and corporate governance and assisting companies in making business decisions. Second, if the company requires costs to develop its business, institutional investors can help the company by providing funding or using its networks.

\section{The Effect of Executive Compensation on Company Performance}

Kagango (2016) states that executive compensation has a significant positive effect on company performance. This is explained, if the executives have a strong interest, then the impact they can cause from the decisions they make for the company will also be more substantial. Thus, companies can improve their performance if the interests held by the executive can be fulfilled by compensation. In addition, the interests of shareholders and the executive can be aligned with the level of compensation received by the executive. If the compensation received is equal, the compensation will be an incentive for the executive to improve company performance.

In addition, Abdalkrim (2019) states that the compensation received by executives will be a trigger for them to improve company performance. In addition, the costs incurred to pay executive compensation can be considered an investment for the company because the leadership abilities possessed by executives can be a guarantee to improve company performance. 


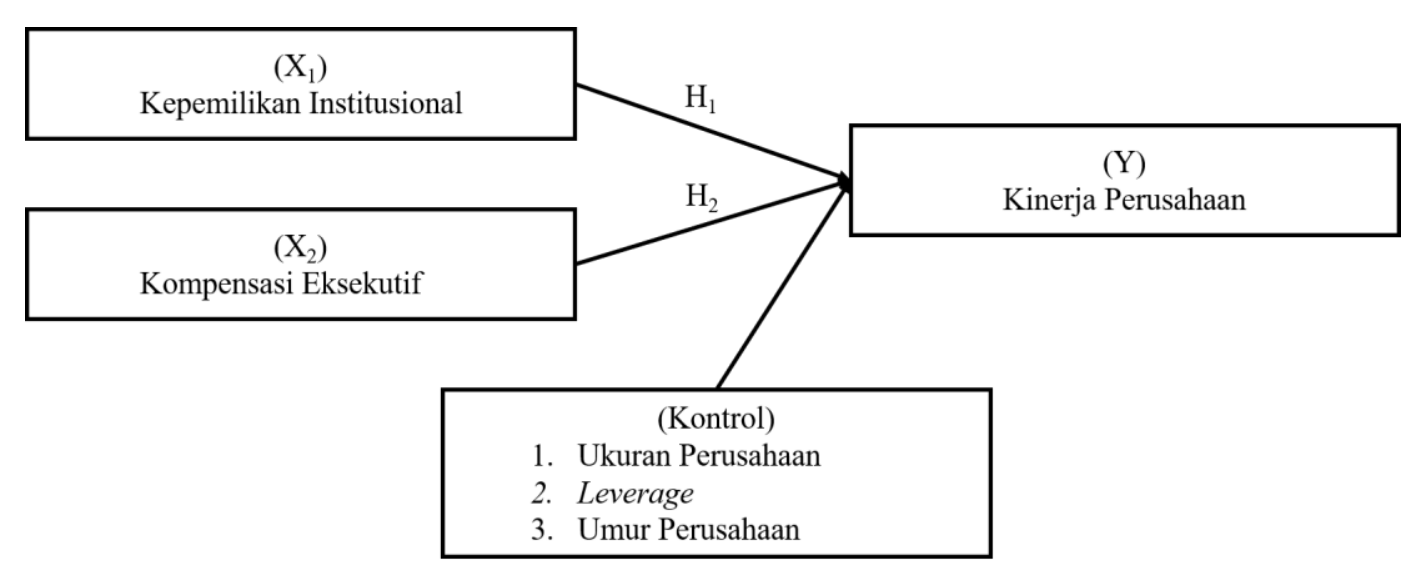

Figure 1. Research Model

\section{RESEARCH METHOD}

This research uses descriptive and associative research methods. The descriptive research method is a research method to describe the phenomena that occur at this time or in the past. The associative research method aims to identify and explain the causal relationship between one variable and another. The analysis technique used in this research is quantitative analy sis because the data used is in the form of numbers with the panel data regression method as a data analysis method.

The objects in this study are institutional ownership, executive compensation, and company performance. The subjects of this research are food and beverage sub-sector companies listed on the Indonesia Stock Exchange in the 2014-2018 period. The data used is secondary data obtained from financial reports and company annual reports.

Sampling in this study using the purposive sampling method, namely sampling, is carried out based on a particular consideration that the researcher has determined. The criteria used to determine the sample to be taken (1) Companies that have been listed on the Indonesia Stock Exchange in 2014 (the first year of the research period), (2) Companies that provide annual reports or financial reports for five consecutive years (2014-2018), and (3) Companies that include data required for research in their annual/financial reports. The population used in this study were all companies in the Food and Beverage subsector listed on the Indonesia Stock Exchange in 2020, totalling 33 companies. Through the purposive sampling technique, the researcher obtained a sample of 16 companies with a research period of five years, so that there were 80 observational data. 
In this study, there are three different types of variables used the dependent variable that will be used is company performance and uses Tobin's Q, ROA (Return on Asset), and ROE (Return on Equity) as proxies. Then the independent variables used in this study are institutional ownership and executive compensation. Finally, the control variables used are company size, leverage (as proxied by Debt to Asset Ratio [DAR]), and company age. In this study, the regression equation model used is divided into using control variables and not using control variables. Each model will be tested three times differently, using the three proxies of company performance, namely Tobin's Q, ROA, and ROE, so that a total of six regressions is carried out. These models have the following equation:

(a) FIRP $=\beta 0+\beta 1$ INSTit $+\beta 2$ COMPit $+\varepsilon$ it

(1) Tobin's $Q=\beta 0+\beta 1$ INSTit $+\beta 2$ COMPit $+\varepsilon i t$

(2) $\mathrm{ROA}=\beta 0+\beta 1 \mathrm{INSTit}+\beta 2 \mathrm{COMPit}+\varepsilon i \mathrm{t}$

(3) $\mathrm{ROE}=\beta 0+\beta 1$ INSTit $+\beta 2 \mathrm{COMPit}+\varepsilon i \mathrm{t}$

(b) FIRP $=\beta 0+\beta 1$ INSTit $+\beta 2$ COMPit $+\beta 3$ SIZEit $+\beta 4$ DARit $+\beta 5$ AGEit $+\varepsilon i t$

(4) Tobin's $Q=\beta 0+\beta 1$ INSTit $+\beta 2$ COMPit $+\beta 3$ SIZEit $+\beta$ 4DARit $+\beta 5 A G E i t+\varepsilon i t$

(5) $\mathrm{ROA}=\beta 0+\beta 1$ INSTit $+\beta 2$ COMPit $+\beta 3$ SIZEit $+\beta 4$ DARit $+\beta 5 A G E i t+\varepsilon i t$

(6) $\mathrm{ROE}=\beta 0+\beta 1 \mathrm{INSTit}+\beta 2 \mathrm{ECOMit}+\beta 3$ SIZEit $+\beta 4 \mathrm{DARit}+\beta 5$ AGEit $+\varepsilon i t$ Explanation:

FIRP = Firm/Company Performance

INST $=$ Institutional Ownership

COMP $=$ Executive Compensation

SIZE = Company Size

DAR = Debt to Asset Ratio

AGE = Company Age 


\section{RESULT AND DISCUSSION}

\section{Normality Test}

The normality test is carried out to determine whether the residual value in the regression model is normally distributed or not. This test is carried out with the Jarque-Bera test, if the probability value of the Jarque-Bera is more significant than 0.05 , the residual is usually distributed. However, if the probability value of Jarque-Bera is smaller than 0.05 , the residuals are not normally distributed. However, after the researcher processed the data, the researcher found problems in the normality test caused by the residual data not generally distributed in all research models. To overcome this, the researcher conducted an outlier test. This is intended to eliminate data with extreme values in observations to be no normality problem in the residual data.

Table 1. Normality Test Resul ts (Before Outlier Test)

\begin{tabular}{|l|l|l|l|}
\hline Model & Jarque-Bera & Probability & Result \\
\hline Model 1 & 365.8517 & 0,0000 & Not Normal \\
\hline Model2 & 115.7334 & 0,0000 & Not Normal \\
\hline Model3 & 370.0002 & 0,0000 & Not Normal \\
\hline Model4 & 286.6317 & 0,0000 & Not Normal \\
\hline Model5 & 145.8425 & 0,0000 & Not Normal \\
\hline Model6 & 727.7407 & 0,0000 & Not Normal \\
\hline
\end{tabular}

Table 2. Normality Test Results (After Outlier Test)

\begin{tabular}{|c|l|l|l|}
\hline Model & Jarque-Bera & Probability & Result \\
\hline Model1 & 4.0996 & 0,1288 & Normal \\
\hline Model2 & 1.9646 & 0,3744 & Normal \\
\hline Model3 & 1.2484 & 0,5357 & Normal \\
\hline Model4 & 1.9359 & 0,3799 & Normal \\
\hline Model5 & 43.1318 & 0,0000 & Not Normal \\
\hline Model6 & 27.1194 & 0,0000 & Not Normal \\
\hline
\end{tabular}

After the outlier test, all models have passed the normality test, except for model 5 and model 6. However, to avoid eliminating a lot of research data, causing too little research data, the outlier test is stopped and the normality test is completed here. 


\section{Multicollinearity Test}

The multicollinearity test aims to see whether the regression model finds a correlation or relationship between the independent variables. If there is no correlation or relationship between the independent variables, it can be said that the regression model is good. If there is a correlation coefficient between variables of more than 0.9 , then the independent variable experiences multicollinearity. For this study, the control variables will also be included in the multicollinearity test.

Table 3. Multicollinearity Test Results

\begin{tabular}{|c|l|l|l|l|l|}
\hline & INST & COMP & Size & DAR & Age \\
\hline INST & 1.0000 & -0.3095 & -0.5460 & 0.1308 & -0.0243 \\
\hline COMP & -0.3095 & 1.0000 & 0.8454 & 0.0840 & -0.5497 \\
\hline Size & -0.5460 & 0.8454 & 1.0000 & -0.1349 & -0.5056 \\
\hline DAR & 0.1307 & 0.0840 & -0.1349 & 1.0000 & -0.0417 \\
\hline Age & -0.0243 & -0.5497 & -0.5056 & -0.0417 & 1,0000 \\
\hline
\end{tabular}

From the results of the multicollinearity test, there is no correlation coefficient between variables that is more than 0.9 . So it can be said that there is no correlation between the independent variables used in this study.

\section{Data Panel Regression}

Table 4. Data Panel Regression Results

\begin{tabular}{|c|c|c|c|c|c|c|}
\hline $\begin{array}{l}\text { Variables } \\
\text { (Prob) }\end{array}$ & $\begin{array}{l}\begin{array}{l}\text { Model 1 } \\
\text { (Tobin's } \\
\text { Q) }\end{array} \\
\end{array}$ & $\begin{array}{c}\text { Model } 2 \\
\text { (ROA) }\end{array}$ & $\begin{array}{c}\text { Model 3 } \\
\text { (ROE) }\end{array}$ & $\begin{array}{c}\text { Model 4 } \\
\text { (Tobin's Q) }\end{array}$ & $\begin{array}{l}\text { Model } 5 \\
\text { (ROA) }\end{array}$ & $\begin{array}{l}\text { Model } 6 \\
\text { (ROE) }\end{array}$ \\
\hline \multirow{2}{*}{ Intercept } & 11.3962 & -0.0536 & 0.8272 & 30.2682 & 1.2006 & 2.3500 \\
\hline & 0.0327 & 0.8976 & 0.2933 & 0.0020 & 0.1217 & 0.0920 \\
\hline \multirow{2}{*}{ INST } & 3.5171 & 0.0886 & 0.1398 & 3.7635 & 0.1128 & 0.2326 \\
\hline & $0.0056^{* *}$ & 0.3641 & 0.4448 & $0.0020 * * *$ & 0.2411 & 0.1788 \\
\hline \multirow{2}{*}{ COMP } & -0.5059 & 0.0028 & -0.0341 & -0.1386 & 0.0302 & 0.0533 \\
\hline & $0.0271 * *$ & 0.8743 & 0.3118 & 0.6293 & 0.2102 & 0.2169 \\
\hline \multirow{2}{*}{ SIZE } & & & & -1.0634 & -0.0703 & -0.1349 \\
\hline & & 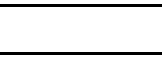 & & $0.0020 * * *$ & $0.0122 * *$ & $0.0077 * * *$ \\
\hline \multirow{2}{*}{ DAR } & & - & & 0.7003 & 0.0144 & 0.1997 \\
\hline & & 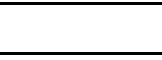 & & 0.4355 & 0.8464 & 0.1402 \\
\hline \multirow{2}{*}{ AGE } & & 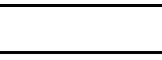 & & -0.0859 & 0.0036 & 0.0057 \\
\hline & & & & 0.1661 & 0.4811 & 0.5335 \\
\hline $\begin{array}{l}\text { Adjusted R- } \\
\text { Squared }\end{array}$ & 0.8876 & 0.5355 & 0.3374 & 0.9072 & 0.5877 & 0.4633 \\
\hline
\end{tabular}




\begin{tabular}{|l|l|l|l|l|l|l|}
\hline $\begin{array}{l}\text { Variables } \\
\text { (Prob) }\end{array}$ & $\begin{array}{l}\text { Model 1 } \\
\text { (Tobin's } \\
\text { Q) }\end{array}$ & $\begin{array}{l}\text { Model } \\
\mathbf{2} \\
\text { (ROA) }\end{array}$ & $\begin{array}{l}\text { Model } \\
\mathbf{3} \\
\text { (ROE) }\end{array}$ & $\begin{array}{l}\text { Model 4 } \\
\text { (Tobin's } \\
\text { Q) }\end{array}$ & $\begin{array}{l}\text { Model 5 } \\
\text { (ROA) }\end{array}$ & $\begin{array}{l}\text { Model 6 } \\
\text { (ROE) }\end{array}$ \\
\hline $\begin{array}{l}\text { Prob (F- } \\
\text { Statistics) }\end{array}$ & 0.0000 & 0.0000 & 0.0020 & 0.0000 & 0.0000 & 0.0002 \\
\hline Observation & 55 & 55 & 55 & 55 & 55 & 55 \\
\hline
\end{tabular}

Based on the results of panel data regression, it can be seen that institutional ownership has a significant positive effect on company performance through the proxy of Tobin's Q, with a probability value below 0.05 ( 0.0056 for model 1 and 0.0020 for model 4 ). Following research from Lin \& Fu (2017) which also measures company performance through Tobin's Q proxy, they explain that institutional ownership can actively monitor business activities carried out by companies, minimize information gaps and agency problems, and help company performance by providing the resources they have to improve it, so that the existence of institutional ownership has a high influence, at least in a market-based manner.

However, institutional ownership has an insignificant positive effect on company performance through the proxies of ROA and ROE, were all probability values in Models 2, 3, 5, and 6 are above 0.05. Research from Amba (2014) explains that institutions that own shares in a company tend to be passive and are more interested in increasing profits for themselves and expanding their portfolios only, so even though the owner institution will help the company improve their performance, the influence they provide will not be significant from an accounting-based perspective.

Then in model 1, executive compensation has a significant effect on company performance as measured by Tobin's Q, with the resulting probability value being below 0.05. However, in other models, executive compensation has an insignificant effect on company performance, wherein in these models (including model 4, which also measures company performance with Tobin's Q), the resulting probability value is above 0.05 . With these results, the researcher concludes that executive compensation does not significantly affect firm performance. Following research from Bianchi \& Chen (2015), they state that there is a possibility that better company performance is the result of the executive's luck in running the company in the first period, and he will be given an increase in compensation in the second period. However, because the company's performance is 
irrelevant to the capabilities and behaviour of the executive, the company's performance may fall to the mean (average) performance in the next period, so that the compensation that the company has given to the executive is useless and insignificant.

\section{Adjusted R2 Test}

This test is used to see how much the independent variable affects the dependent variable. The coefficient of determination close to one means that the independent variables almost provide all the information needed to predict the dependent variable.

Table 5 Adjusted $\mathbf{R}^{2}$ Test Results

\begin{tabular}{|l|l|l|l|l|l|l|}
\hline & $\begin{array}{l}\text { Model 1 } \\
\text { (Tobin's Q) }\end{array}$ & $\begin{array}{c}\text { Model 2 } \\
\text { (ROA) }\end{array}$ & $\begin{array}{c}\text { Model 3 } \\
\text { (ROE) }\end{array}$ & $\begin{array}{l}\text { Model 4 } \\
\text { (Tobin's Q) }\end{array}$ & $\begin{array}{c}\text { Model 5 } \\
\text { (ROA) }\end{array}$ & $\begin{array}{c}\text { Model 6 } \\
\text { (ROE) }\end{array}$ \\
\hline $\begin{array}{r}\text { Adjusted } \\
\text { R-Squared }\end{array}$ & 0,8876 & 0,5355 & 0,3374 & 0,9072 & 0,5877 & 0,4633 \\
\hline
\end{tabular}

Of all the research models tested, based on the adjusted R-squared value, the fittest model is model 4 because it has the highest adjusted R-squared value, namely 0.9072 (90.72\%). This model can be formulated into:

$$
\text { Tobin's Q }=30.2682+3.7635 \text { INST }-0.13886 \text { COMP }-1.0634 \text { SIZE }+0.7003
$$

$$
\text { DAR - 0.0859 AGE }
$$

The result indicates that all the independent variables used in Model 4 can predict changes in the dependent variable by $90.72 \%$.

\section{CONCLUSION}

Companies, so that the existence of institutional ownership has a significant influence, at least in a market-based manner. Institutional ownership has a significant positive effect on company performance in Tobin's Q proxy. This is because institutional ownership can actively oversee business activities carried out by the company, minimize information gaps and agency problems, and help company performance by providing the resources it has to improve performance.

Accounting-based. However, institutional ownership does not affect company performance through the proxies of ROA and ROE. This is because institutions that own 
shares in a company tend to be passive and are more interested in increasing profits and expanding their portfolios only. Even though the institutional owners will help companies improve their performance, their influence is not very significant in their perspective. Then, executive compensation does not affect company performance. This is because the possibility of better company performance is the result of the executive's luck in running the company in the first period, and he will be given an increase in compensation in the second period. However, because the company's performance is irrelevant to the capabilities and behaviour of the executive, the company's performance may fall to the mean (average) performance in the next period, so that the compensation that the company has given to the executive is useless and insignificant.

This research is expected to be a scientific and informative consideration, especially for companies, especially food and beverage companies, in making the right policies in maximizing the role and benefits of institutional ownership so that their existence can maximize company performance not only market-based but also on an accounting-based basis. In addition, the company must also provide appropriate compensation to executives to ensure that the compensation provided can provide good results for the company. In addition, this research is expected to be an informative consideration for investors when choosing companies, especially food and beverage companies, to invest in. Investors can make decisions based on institutional ownership and executive compensation in the company. This will indirectly have an impact on other company policies that can influence investors in investing.

Then, several recommendations can be implemented by further research that has similar subjects to this study:

1. Further research can add variables that consider other factors within the company, such as other Good Corporate Governance variables, and use financial ratios that can see the company's performance more technically so that the results obtained are more varied.

2. Expanding the object of research, not only researching food and beverage companies but also companies operating in other industries, the research results are more varied. 


\section{References}

Abdalkrim, G. (2019). Chief executive officer compensation, corporate governance and performance: evidence from KSA firms. Corporate Governance (Bingley), 19(6), $1216-1235$.

Amba, S. M. (2014). Corporate governance and firms' financial performance.

Journal of Academic and Business Ethics, 1-11.

Anggraini, S., Yunilma, \& Fauziati, P. (2014). Faktor-faktor yang Mempengaruhi Pemberian Kompensasi Kepada Dewan Direksi di Perusahaan yang Go Public di Indonesia. E-Jurnal Universitas Bung Hatta, 4(1), 1-13.

Berger, A. N., Kick, T., Koetter, M., \& Schaeck, K. (2013). Does it pay to have friends? Social ties and executive appointments in banking. Journal of Banking and Finance, 37(6), 2087-2105.

Bianchi, G., \& Chen, Y. (2015). CEO compensation and the performance of firms in the hospitality industry: a cross-industry comparison. International Journal of Tourism Sciences, 15(3-4), 121-138.

Fadillah, A. R. (2017). Analisis Pengaruh Dewan Komisaris Independen, Kepemilikan Manajerial dan Kepemilikan Institusional terhadap Kinerja Perusahaan yang Terdaftar Di LQ45. Jurnal Akuntansi, 12(1), 37-52.

Fazlzadeh, A., Hendi, A. T., \& Mahboubi, K. (2011). The Examination of the Effect of Ownership Structure on Firm Performance in Listed Firms of Tehran Stock Exchange Based on the Type of the Industry. International Journal of Business and Management, 6(3), 249-266.

Halim, H. A., \& Christiawan, Y. J. (2019). Pengaruh Penerapan Corporate Governance Terhadap Nilai Perusahaan Dengan Kinerja Keuangan Sebagai Variabel Mediasi. Diponegoro Journal of Accounting, 8(4), 181- 192.

Kagango, S. (2016). The Impact of CEO Compensation on Firm Performance: The Gender Perspective. SSRN Electronic Journal, April. 
Lin, Y.R., \& Fu, X. M. (2017). Does institutional ownershipinfluencefirm performance? Evidence from China. International Review of Economics and Finance, 49 (October 2016), 17-57.

Maharani, W. P., \& Utami, E. R. (2019). Pengaruh Kepemilikan Institusional terhadap Kompensasi Eksekutif yang Dimediasi oleh Kinerja Perusahaan. Jurnal Reviu Akuntansi dan Keuangan, 9(1), 85-96.

Matolcsy, Z., Shan, Y., \& Seethamraju, V. (2012). The timing of changes in CEO compensation from cash bonus to equity-based compensation: Determinants and performance consequences. Journal of Contemporary Accounting and Economics, 8(2), 78-91.

Mirawati, K., \& Wulansari, M. (2018) Pengaruh Mekanisme Good Corporate Governance, Debt to Equity Ratio, Asset Growth terhadap Kinerja Perusahaan(Studi Empiris pada Perusahaan Pertambangan yang Terdaftar di Bursa Efek Indonesia, Thailand, Malaysia Periode 2013-2017). Jurnal Dinamika Manajemen dan Bisnis, 1 (2).

Novari, P., \& Lestari, P. (2016). Pengaruh Ukuran Perusahaan, Leverage, dan Profitabilitas terhadap Nilai Perusahaan pada Sektor Properti dan Real Estate. EJurnal Manajemen Universitas Udayana, 5(9), 252428.

Nugraha, R. (2018) Analisis Pengaruh Capital/Labour Intensive, Investasi, Kepemilikan Manajerial, Leverage Operasi dengan Variabel Mediasi Kebijakan Dividen dan Leverage Keuangan terhadap Nilai Perusahaan. Jurnal Dinamika Manajemen dan Bisnis, 1 (1).

Nurwati, E., Achsani, N. A., Hafidhuddin, D., \& Nuryartono, N. (2014). Umur dan Kinerja Perusahaan: Studi Empiris Perbankan Syariah di Indonesia. Jurnal Manajemen Teknologi, 13(2), 173-188.

Rahmawati, N., \& Handayani, R. (2017). Analisis Pengaruh Karakteristik Corporate Governance Terhadap Kinerja Perusahaan (Studi Empiris pada Perusahaan 
Manufakturyang Terdaftar di Bursa Efek Indonesia periode 2010-2014). Diponegoro Journal of Accounting, 6(3), 26-37.

Sari, R. A. I., \& Priyadi, M. P. (2016). Pengaruh Leverage, Profitabilitas, Size, dan Growth Opportunity terhadap Nilai Perusahaan. Jurnal Ilmu dan Riset Manajemen, 5(10), 2-17.

Wulandari, T. (2013). Analisis Pengaruh Political Connection dan Struktur Kepemilikan terhadap Kinerja Perusahaan. Analisis Pengaruh Political Connection dan Struktur Kepemilikan Terhadap Kinerja Perusahaan, 2(1), 141-152. 